\title{
The Effects of Media Exposure to Students' Core Values
}

\author{
Mary Ann A. Balanza ${ }^{1^{*}}$, PhD, Darin Jan C. Tindowen ${ }^{2}$, PhD \\ ${ }^{\text {I}}$ Cagayan National High School, Philippines \\ ${ }^{2}$ University of Saint Louis, Philippines
}

*Corresponding Author: Mary Ann A. Balanza, Cagayan National High School, Philippines

\begin{abstract}
This study is conducted to identify the effects of media exposure to students' core values. Descriptive correlational method was utilized in the study with 380 students and 50 teachers in a Catholic Educational institution in Northern Philippines. Results revealed that media exposure greatly influenced the manifestation of students on their school's core values which are true Christian living, academic excellence, professional responsibility and social involvement and awareness. Further, there is a significant difference on the assessment of teachers and students on the manifestation of core values and media exposure. Finally, educational level greatly influences the media exposure and manifestations of core values of students.
\end{abstract}

Keywords: Core Values, Media Exposure, True Christian Living, Academic Excellence, Professional Responsibility, Social Involvement and Awareness

\section{INTRODUCTION}

As the third millennium of the Christian era begins, humankind is well along in creating a global network for the instantaneous transmission of information, ideas, and value judgments in science, commerce, education, entertainment, politics, the arts, religion, and every other field. And one of key players in this globalized era is media. The use of media is recognizable and undeniably reaching all forms of institutions including the church, family, schools and government. In fact, the church uses the various instruments of mass media in promoting genuine Christian values [1] [2] [3]. Schools use media in making learning become more relevant. Government use media to disseminate pertinent and urgent national concerns to the people. With all these, media become instrumental in the integral growth of all people. Media has become one of the basic needs of the people, so that without, they could hardly live their life in its fullness [4]. It makes the lives of the people without any difficulty, along with information and communication technologies. Families continue to nurture relationships with their members who work abroad because of media. People around the world become more socially and politically aware because of media.

Media is an important and effective tool in the process of information dissemination. Through media, people are informed about: what is happening around the world; the worth emulating people; the important inventions for better living; the current trends that keeps people updated; and the technology that shortens the distance from love ones [5]. Information provided by media is influential in the lifestyle of a person that it even creates needs of a person who is living a very simple life. It pushes the people to move and work for a lifestyle promoted by media [6] [7]. Media influences a lot of person to the point of setting a norm for the people to follow. Movie actors and actresses for example would simply declare to the public that they are living together but not married or would simply that their marriage is not anymore working and they simply have to file for an annulment or legal separation. The indiscriminate public would think that it is just alright to do that and would follow. Magazines contain models with beautiful bodies, which is encouraging the readers to do something also to have a beautiful body. Indeed they are silently influencing the value of a person especially by the one who has not established well himself/herself.

Undeniably, media being a means of communications has an important role to fulfill in a community. There is an inescapable need for media especially in moving towards globalization. Even classroom teachings are enhanced through the use of media. As an effect of the enhanced teachings, students become focused and consequently become better learners. Needed information become easily accessible because of media. A purposeful, deeper and more sophisticated learning can occur. 
In a Catholic Higher Education institution in Tuguegarao City, Northern Philippines, students are not exempted from being exposed to media. They are sometimes heard talking about situations, fashion, people, and online games, which the teachers are not aware of. Despite the promotion of the core values of the institution- true Christian living, academic excellence, professional responsibility, and social awareness and involvement- it is inevitable that students would also learn these values from the different types of media.

Catholic educational institution does not only promote the academic formation of the students. Rather, she upholds the integral formation of every student, which is reflected in her vision-mission [8]. These core values are expected to be carried by every student even outside the school, in any circumstance, even amidst the enormous influences and dreadful effects of media [9] [10]. It is for this reason that this study is formulated. It attempts to unveil the effect of students' exposure to media to the core values they are expected to live.

\subsection{Research Objectives}

This study attempted to determine the media exposure of students and it effects to their practice and manifestation of their institutional core values. Specifically it tries to answer the following objectives: (1) to determine the profile of the students along gender, educational level, economic status, religion, ethnicity, and parents' educational level; (2) to determine the media exposure characteristics of the respondents along the type of media they exposed to and their frequency of exposure; (3) to determine the extent in which the different media affect the core values of the students as perceived by themselves and their teachers; (4) to determine the significant difference on the perceptions of the students and teachers as to the effects of media to students' core values; and (4) to determine the significant relationship between the effects of media exposure and the profile of the students vis-à-vis their institutional core values.

\section{METHODS}

The study used the correlational-survey method in evaluating the relationship between the students' exposure to media and their institutional core values. The 380 respondents of the study, which were selected through stratified random sampling, were the students of a Catholic Educational Institution in Tuguegarao City, Northern Philippines from high school level to tertiary level. Further, to validate the findings of the study, 50 secondary teachers and college instructors were also part of the study.

A researcher-made questionnaire was the primary tool in eliciting information for this study. The questionnaire has three parts. Part 1 covers the profile variables such as gender, educational level, economic status, religion, ethnicity, parent's educational level. Part 11 includes media exposure characteristics of the respondents in terms of type of media exposed to and frequency of exposure. The third part is finding out the extent to which the different media affect the Louisian core values of the respondents. The extent of effect is measured through the use of the 5 point Likert scale. Content validity index and reliability test were performed before the conduct of the study to assure the reliability and validity of the questionnaire. Result of the Content Validity Index and Reliability test, with 0.80 and 0.90 values respectively, imply that the questionnaire is valid and reliable.

And for the data analysis, simple frequency counts and percentage, weighted mean, independent sample t-test, one way analysis of variance test, and chi-square test were utilized to answer the research objectives of the study.

\section{RESULTS AND DISCUSSION}

Table1. Profile of the Student-Respondents

\begin{tabular}{|c|c|c|}
\hline Profile & Frequency & Percentage \\
\hline \multicolumn{3}{|l|}{ Gender } \\
\hline Male & 141 & 37.20 \\
\hline Female & 239 & 62.80 \\
\hline Total & 380 & 100.00 \\
\hline \multicolumn{3}{|l|}{ Educational Level } \\
\hline Secondary & 100 & 26.31 \\
\hline Tertiary & 280 & 73.69 \\
\hline Total & 380 & 100.00 \\
\hline
\end{tabular}




\begin{tabular}{|c|c|c|}
\hline Family Monthly Income & & \\
\hline below 10,000 & 127 & 33.51 \\
\hline above 10,000 to 20,000 & 140 & 36.94 \\
\hline above 20,000 to 30,000 & 45 & 11.87 \\
\hline above 30,000 to 40,000 & 25 & 6.60 \\
\hline above 40,000 to 50,000 & 14 & 3.69 \\
\hline above 50,000 to 60,000 & 14 & 3.69 \\
\hline above 60,000 to 70,000 & 7 & 1.85 \\
\hline above 80,000 to 90,000 & 1 & 0.26 \\
\hline above 90,000 to 100,000 & 1 & 0.26 \\
\hline above 100,000 & 6 & 1.32 \\
\hline Total & 380 & 100.00 \\
\hline \multicolumn{3}{|l|}{ Religion } \\
\hline Roman Catholic & 323 & 84.96 \\
\hline Born Again & 25 & 6.60 \\
\hline Church of Christ of the Latter Day Saints & 3 & 0.79 \\
\hline Aglipayan & 2 & 0.53 \\
\hline Jehovah's Witness & 4 & 1.06 \\
\hline Iglesia ni Kristo & 4 & 1.06 \\
\hline Methodist & 12 & 3.17 \\
\hline Pentecost & 3 & 0.79 \\
\hline Seventh Day Adventist & 4 & 1.06 \\
\hline (1) & 380 & 100.00 \\
\hline \multicolumn{3}{|l|}{ Ethnicity } \\
\hline Ilocano & 146 & 38.26 \\
\hline Ibanag & 72 & 19.00 \\
\hline Itawes & 63 & 16.62 \\
\hline Kalinga & 8 & 2.11 \\
\hline Ifugao & 1 & 0.26 \\
\hline Ivatan & 2 & 0.53 \\
\hline Tagalog & 81 & 21.37 \\
\hline Malaueg & 6 & 1.59 \\
\hline Isneg & 1 & 0.26 \\
\hline Total & 380 & 100.00 \\
\hline \multicolumn{3}{|l|}{ Fathers' Educational Attainment } \\
\hline Elementary Graduate & 23 & 6.07 \\
\hline High School Graduate & 113 & 29.55 \\
\hline College Graduate & 244 & 64.38 \\
\hline $\begin{array}{rr} & \text { Total } \\
\end{array}$ & 380 & 100.00 \\
\hline \multicolumn{3}{|l|}{ Mothers' Educational Attainment } \\
\hline Elementary Graduate & 21 & 5.54 \\
\hline High School Graduate & 80 & 20.84 \\
\hline College Graduate & 279 & 73.61 \\
\hline Total & 380 & 100.00 \\
\hline
\end{tabular}

The table presents the profile of the student-respondents in the study. It can be gleaned in the table that there are more female than male respondents in the study. Also, in terms of their educational level, there are more than college students than high school students. In terms of their monthly family income, it can be shown in the results that majority of the respondents have an average monthly income of below PhP 20,000.00. Also, in terms of their religion, most of the respondents are Roman Catholic due to the fact that the institution is a Roman Catholic educational institution supervised by a missionary congregation. However, it is also important to note that there are substantial numbers of non-Catholics who are enrolled in a Catholic institution. The findings affirm the studies of Tindowen [8] and Donlevy [11] that Catholic Educational Institutions nowadays already accept Non-Catholics to be part of their institutions since it the Roman Catholic Church is advocating the value of ecumenism and interreligious dialogue as part of its missionary and religious activity. Meanwhile, in terms of the 
respondents' ethnicity, majority of the respondents are Ilocano. In terms of parents' educational attainment of the respondents, majority are college graduates.

Table2. Media Exposure of the Student-Respondents

\begin{tabular}{|c|c|c|}
\hline Type Of Media Exposed To & Frequency & Percentage \\
\hline \multicolumn{3}{|l|}{ Print Media } \\
\hline Newspaper & 279 & 73.61 \\
\hline Journals & 107 & 28.23 \\
\hline Magazine & 299 & 78.89 \\
\hline Comics & 190 & 50.13 \\
\hline \multicolumn{3}{|l|}{ Broadcast Media } \\
\hline Radio & 324 & 85.49 \\
\hline Music Player & 285 & 75.20 \\
\hline DVD & 262 & 69.13 \\
\hline PSP & 41 & 10.82 \\
\hline Television & 358 & 94.46 \\
\hline \multicolumn{3}{|l|}{$\begin{array}{ll}\text { Electronic Media } \\
\end{array}$} \\
\hline E-mail (Gmail, YahooMail, etc) & 234 & 61.74 \\
\hline Twitter & 76 & 20.05 \\
\hline Youtube & 221 & 58.31 \\
\hline Mobile Phones & 368 & 97.10 \\
\hline Yahoo Messenger (YM) & 217 & 57.26 \\
\hline Facebook & 376 & 98.94 \\
\hline Network/on-line games & 114 & 30.08 \\
\hline Other Social Networking Sites (Instagram, Chikka, etc) & 211 & 55.52 \\
\hline Educational Networking Sites (Academia, Linked, ResearchGate, etc) & 52 & 13.68 \\
\hline
\end{tabular}

Table 2 presents the different types of media to which the students are exposed to. Under print media, $78.89 \%$ are exposed to magazine, $73.61 \%$ are exposed to newspaper, $50.13 \%$ are exposed to comics and $28.23 \%$ are exposed to journal.

In terms of type of broadcast media exposed to, $94.46 \%$ of the students are exposed to Television, $85.49 \%$ to Radio and $75.20 \%$ to Music Player. On the other hand, only $10.62 \%$ are exposed to Portable Play Station (PSP), 17.68\%. Meanwhile, the top most electronic media to which the students are exposed to are Facebook, mobile phones, emails, yahoo messenger, Youtube, and other social networking sites. Meanwhile, Twitter and educational networking sites are the least types of electronic media that they are exposed to.

Taken in general, Facebook, Mobile phones, and televisions are forms of media that they are exposed to. On the other hand, they are least exposed to Portable Play Station (PSP), Video Cassette Recorder (VCR) and Chikka Messenger with percentages of 10.82\%, $17.68 \%$ and $20.05 \%$ respectively. This means that the most common types of media to which the students are exposed to are the mobile phone, television and radio. The findings coincide with the results of previous studies that indeed Facebook is considered as the most preferred social networking sites especially for the teens and university students [12] [13]. However, there are still few students who are not exposed to the mentioned forms of media. The least common forms of media for the students are Twitter, PSP, and educational networking sites. It is important to note that students are already exposed to different educational networking sites. Ellison [14] stressed that these educational networking sites allow students to explore scientific articles and studies that they can use in their academics and even in their professional undertakings. Meanwhile, it can be gleaned on the result that students are exposed to different types of media of different forms. This further shows that most of the respondents are exposed to electronic media and broadcast media. Although some forms of electronic and broadcast media are also the least forms of media to which the respondents are exposed to.

Table3. Frequency and Percentage Distribution of the Respondents' Media Exposure Characteristics in terms of Frequency of their Exposure to Media

\begin{tabular}{|l|c|c|c|c|c|c|}
\hline \multirow{2}{*}{ No. of Hours of Exposure } & \multicolumn{5}{|c|}{ Types of Media Exposed to } \\
\cline { 2 - 7 } & \multicolumn{2}{|c|}{ Print Media } & \multicolumn{2}{c|}{ Broadcast Media } & \multicolumn{2}{c|}{ Electronic Media } \\
\cline { 2 - 7 } & $\mathrm{F}$ & $\%$ & $\mathrm{~F}$ & $\%$ & $\mathrm{~F}$ & $\%$ \\
\hline 1 to 2 & 280 & 73.88 & 21 & 5.54 & 6 & 1.58 \\
\hline 3 to 4 & 80 & 21.11 & 158 & 41.69 & 151 & 39.84 \\
\hline
\end{tabular}

International Journal of Humanities Social Sciences and Education (IJHSSE) 


\begin{tabular}{|l|c|c|c|c|c|c|}
\hline 5 to 6 & 12 & 3.17 & 146 & 38.52 & 139 & 36.68 \\
\hline 7 to 8 & 6 & 1.58 & 44 & 11.61 & 68 & 17.94 \\
\hline 9 to 10 & 1 & 0.26 & 10 & 2.64 & 15 & 3.96 \\
\hline Total & 379 & 100 & 379 & 100 & 379 & 100 \\
\hline Mean Hours of Exposure & \multicolumn{2}{|c|}{2.16} & \multicolumn{2}{|c|}{4.78} & \multicolumn{2}{c|}{5.16} \\
\hline SD & \multicolumn{2}{|c|}{1.29} & \multicolumn{2}{|c|}{1.71} \\
\hline
\end{tabular}

It can be observed from table 3.b that $73.88 \%$ of the respondents are exposed to print media for 1 to 2 hours while $0.26 \%$ is exposed to it for 9 to 10 hours. Furthermore, the number of students who are exposed to print media decreases as the number of hours of exposure increases. This implies that most students do not do long hours of reading printed materials.

On the area of broadcast media, $41.69 \%$ of the population is exposed to it for 3 to 4 hours, and close to that percentage is $38.52 \%$ for 5 to 6 hours, while there are $2.64 \%$ who are exposed to it for 9 to 10 hours. This means that the students are exposed longer to broadcast media than that of the print media.

Similar to students' exposure to broadcast media, $39.84 \%$ of the respondents are exposed to electronic media for 3 to 4 hours, $36.68 \%$ are exposed to it for 5 to 6 hours, while $3.96 \%$ are exposed to it for 9 to 10 hours. This means that like their exposure to broadcast media, the students are exposed longer to electronic media than that of the print media. The findings affirm the results of previous studies that indeed, electronic media is considered as the most preferred type of media being utilized especially by university and college students due to its easy accessibility and utilization [15] [16].

\subsection{Effects of Media Exposure to Students' Core Values}

Table4a. Effects of Exposure to Media to the Core Value of True Christian Living of the Students as Perceived by the Students and the Teachers

\begin{tabular}{|l|l|l|l|l|}
\hline \multirow{2}{*}{ Effects of Being Exposed to Different Forms } & \multicolumn{2}{|c|}{ Students } & \multicolumn{2}{|c|}{ Teachers } \\
\cline { 2 - 6 } & Mean Media & Descriptive Value & Mean & Descriptive Value \\
\hline $\begin{array}{l}\text { The students are constantly reminded of the } \\
\text { gospel values through the media. }\end{array}$ & 3.34 & Moderate extent & 3.26 & Moderate extent \\
\hline $\begin{array}{l}\text { The students have realized that they should thank } \\
\text { God that their material condition in life is not the } \\
\text { worst condition. }\end{array}$ & 4.40 & Very great extent & 3.55 & Great extent \\
\hline $\begin{array}{l}\text { They became conscious of the effects of their acts } \\
\text { and words to other people because of the media. }\end{array}$ & 3.59 & Great extent & 3.30 & Moderate extent \\
\hline $\begin{array}{l}\text { Whenever they pray, they include in their prayers } \\
\text { the situation of people featured in news. }\end{array}$ & 3.55 & Great extent & 3.14 & Moderate extent \\
\hline $\begin{array}{l}\text { They became understanding of the feelings of } \\
\text { others because of the messages from the media. }\end{array}$ & 3.80 & Great extent & 3.35 & Moderate extent \\
\hline Weighted Mean & $\mathbf{3 . 7 3}$ & Great extent & $\mathbf{3 . 3 2}$ & Moderate extent \\
\hline
\end{tabular}

\section{Legend:}

$\begin{array}{lll}4.21-5.00 & - & \text { very great extent } \\ 3.41-4.20 & - & \text { great extent } \\ 2.61-3.40 & - & \text { moderate extent } \\ 1.81-2.60 & - & \text { least extent } \\ 1.00-1.80 & - & \text { no extent }\end{array}$

Table 4.a presents the effect of media exposure to the True Christian Living value of the students. It shows that with a mean of 4.40 , the students perceive to a very great extent that they have realized that they should thank God that their material condition is not the worst condition, while the teachers perceive the effect only to a great extent with a mean of 3.55 .

The students also perceive that because of media, they became conscious of the effects of their acts and words to other people, they include in their prayers the situation of other people featured in news, and they become understanding of the feelings of others, to a great extent with a mean of $3.59,3.55$ and 3.80 respectively. The teachers however, perceived that the mentioned effects of media are only to a moderate extent with a mean of 3.30, 3.14 and 3.35 respectively. White [17] stressed that indeed, media utilization greatly influence the religiosity and spirituality especially among college students. 
The students and teachers are unanimous in their perception that media has affected the students to be constantly reminded of the gospel values to a moderate extent with a mean of 3.34 and 3.26 respectively.

In general, exposure to media is affecting the True Christian Living value of the students to a great extent as perceived by the students themselves, and to a moderate extent as perceived by teachers.

Table4b. Effects of Exposure to Media to the Core Value of Academic Excellence of the Students as Perceived by the Students and the Teachers

\begin{tabular}{|l|l|l|l|l|}
\hline \multicolumn{1}{|c|}{$\begin{array}{c}\text { Effects Of Being Exposed To } \\
\text { Different Forms Of Media }\end{array}$} & \multicolumn{2}{|c|}{ Students } & \multicolumn{2}{c|}{ Teachers } \\
\cline { 2 - 5 } & Dean & Descriptive Value & Mean & Descriptive Value \\
\hline $\begin{array}{l}\text { They can discuss events in class because } \\
\text { of being informed by the media. }\end{array}$ & 3.53 & Great extent & 4.02 & Great extent \\
\hline $\begin{array}{l}\text { Their academic performance in school } \\
\text { improved because of their exposure to } \\
\text { different forms of media. }\end{array}$ & 3.44 & Great extent & 3.62 & Great extent \\
\hline $\begin{array}{l}\text { They always challenge themselves to be } \\
\text { at par with international standards after } \\
\text { seeing the international products or output. }\end{array}$ & 3.33 & Moderate extent & 3.44 & Great extent \\
\hline $\begin{array}{l}\text { They became creative in doing things } \\
\text { because of ideas suggested by the media. }\end{array}$ & 3.77 & Great extent & 3.87 & Great extent \\
\hline $\begin{array}{l}\text { Their vocabulary was enriched because } \\
\text { of the media. }\end{array}$ & 3.79 & Great extent & 3.63 & Great extent \\
\hline Weighted Mean & $\mathbf{3 . 5 7}$ & Great extent & $\mathbf{3 . 7 2}$ & Great extent \\
\hline
\end{tabular}

\section{Legend:}

$\begin{array}{lll}4.21-5.00 & - & \text { very great extent } \\ 3.41-4.20 & - & \text { great extent } \\ 2.61-3.40 & - & \text { moderate extent } \\ 1.81-2.60 & - & \text { least extent } \\ 1.00-1.80 & - & \text { no extent }\end{array}$

Table 4.b reveals the effect of exposure to media to the Academic Excellence core value of the students. As revealed in the table, the students perceive that they can discuss events in class because of being informed by media, their academic performance improved, they became creative in doing things because of ideas suggested by media, and their vocabulary was enriched because of the media, to a great extent, with a mean of $3.53,3.44,3.77$ and 3.79 respectively. The teachers perceive the same effects also to a great extent, with mean of 4.02, 3.62, 3.87 and 3.63 respectively. The study of Mehmood and Tawir [18] explicated that indeed, exposure of students to media positively influence educational performance of students since students gained additional knowledge and honed their expertise in their field due to their online immersion to different types of media. Further, Boyd [19[ Coyle [20] and Rithika [21] stressed that students used the different types of media academically since these are their primary way of obtaining information and resources. Meanwhile, the students perceive that their exposure to media has influenced them to be at par with international standards after seeing the international products or output, only to a moderate extent, with a mean of 3.33 . While the teachers perceive that the effect is to a great extent with a mean of 3.44.

Generally, both students and teachers perceive that exposure to media is affecting the academic excellence of students to a great extent, with mean of 3.57 and 3.72 respectively.

Table4c. Effects of Exposure to Media to the Core Value of Professional Responsibility of the Students as Perceived by the Students and the Teachers

\begin{tabular}{|l|c|c|c|c|}
\hline Effects Of Being Exposed To Different Forms & \multicolumn{2}{|c|}{ Students } & \multicolumn{2}{|c|}{ Teachers } \\
\cline { 2 - 5 } Of Media & Mean & Descriptive Value & Mean & Descriptive Value \\
\hline $\begin{array}{l}\text { They developed the self-discipline not to get } \\
\text { hooked to easily accessible and addictive material } \\
\text { ls presented by the media. }\end{array}$ & 3.73 & Great extent & 3.29 & Moderate extent \\
\hline $\begin{array}{l}\text { They aspire to be a professional in the future } \\
\text { because of what is presented by the media. }\end{array}$ & 4.06 & Great extent & 3.74 & Great extent \\
\hline
\end{tabular}




\begin{tabular}{|l|c|c|c|c|}
\hline $\begin{array}{l}\text { They were inspired to pay serious attention to } \\
\text { their studies so that they could be qualified by the } \\
\text { demands of the society because of the media. }\end{array}$ & 3.90 & Great extent & 3.40 & Moderate extent \\
\hline $\begin{array}{l}\text { They became discrete in the information that they } \\
\text { accept and reject because of the media. }\end{array}$ & 3.43 & Great extent & 3.50 & Great extent \\
\hline $\begin{array}{l}\text { They became prompt in accomplishing reports and } \\
\text { assignments because of easy access to the media. }\end{array}$ & 3.76 & Great extent & 3.54 & Great extent \\
\hline Weighted Mean & 3.77 & Great extent & 3.49 & Great extent \\
\hline
\end{tabular}

\section{Legend:}

$\begin{array}{lll}4.21-5.00 & - & \text { very great extent } \\ 3.41-4.20 & - & \text { great extent } \\ 2.61-3.40 & - & \text { moderate extent } \\ 1.81-2.60 & - & \text { least extent } \\ 1.00-1.80 & - & \text { no extent }\end{array}$

Table 4.c presents the effect of media exposure to the Professional Responsibility value of the respondents. It reveals that the students and teachers perceive that the exposure of the students to the different forms of media is affecting their value along professional responsibility to a great extent.

Although teachers perceive that exposure to media is affecting the professional responsibility of students also to a great extent in general, they differ from the perception of the students on some details. Specifically, students perceive that they don't easily get hooked to easily accessible and addictive materials presented by the media to a great extent, with a mean of 3.73, while teachers perceive that the effect is to a moderate extent with a mean of 3.29. Because of what is presented by media, students and teachers perceive that students aspire to be a professional in the future, to a great with a mean of 4.06 and 3.74 respectively. According to students, they were inspired to pay serious attention to their studies so that they could be qualified by the demands of the society to a great extent, with a mean of 3.90, while according to teachers, the effect is only to a moderate extent, with a mean of 3.40. The students became discrete in the information that they accept and reject to a great extent, as perceived by themselves and teachers with a mean of 3.43 and 3.50 respectively. As perceived by students, with a mean of 3.76 , and teachers with a mean of 3.54 , the students became prompt in accomplishing reports and assignments to a great extent.

Table4d. Effects of Exposure to Media to the Core Value of Social Awareness and Involvement of the Students as Perceived by the Students and the Teachers

\begin{tabular}{|l|c|c|c|c|}
\hline \multicolumn{1}{|c|}{$\begin{array}{c}\text { Effects Of Being Exposed To Different } \\
\text { Forms Of Media }\end{array}$} & \multicolumn{2}{|c|}{ Students } & \multicolumn{2}{|c|}{ Teachers } \\
\cline { 2 - 5 } & Mean & Descriptive Value & Mean & Descriptive Value \\
\hline $\begin{array}{l}\text { They are aware of what is happening in the } \\
\text { country through media and think of ways on how } \\
\text { to be involved with any circumstance that the } \\
\text { country is undertaking. }\end{array}$ & 3.94 & Great extent & 3.91 & Great extent \\
\hline $\begin{array}{l}\text { It became easy for them to cope with different } \\
\text { situations in life because of what the media } \\
\text { models have shown. }\end{array}$ & 3.77 & Great extent & 3.69 & Great extent \\
\hline $\begin{array}{l}\text { They felt the sense of belonging whenever media } \\
\text { suggests that every citizen participates in a } \\
\text { national cause. }\end{array}$ & 3.57 & Great extent & 3.64 & Great extent \\
\hline $\begin{array}{l}\text { They were encouraged to share their things to } \\
\text { others as they see and hear others share their } \\
\text { things to the victims of calamities. }\end{array}$ & 3.72 & Great extent & 3.68 & Great extent \\
\hline $\begin{array}{l}\text { It became easier for them to socialize wherever } \\
\text { they go because of a common knowledge to talk } \\
\text { about as provided by the media. }\end{array}$ & 3.79 & Great extent & 3.83 & Great extent \\
\hline Weighted Mean & 3.76 & Great extent & 3.75 & Great extent \\
\hline
\end{tabular}

\section{Legend:}

$\begin{array}{lll}4.21-5.00 & - & \text { very great extent } \\ 3.41-4.20 & - & \text { great extent }\end{array}$ 


$\begin{array}{lll}2.61-3.40 & - & \text { moderate extent } \\ 1.81-2.60 & - & \text { least extent } \\ 1.00-1.80 & - & \text { no extent }\end{array}$

Table 4.d shows the effect of media exposure to the value of the students along social awareness and involvement. As presented by the table, students and teachers both perceived that exposure to media is affecting the social awareness and involvement value of the students to a great extent, with a mean of 3.76 and 3.75. The findings imply that students' exposure to different types of media greatly affects their manifestation on the core value of social involvement and awareness. Kahne and Middaugh [22] revealed in their study that college students are become socially involved and actively participated on the different societal issues because of their exposure to media, specifically to social media and television.

Students and teachers both perceived that students are aware of what is happening in the country through media and think of ways on how to be involved with any circumstance that the country is undertaking, to a great extent with mean of 3.94 and 3.91. They both perceived that it became easy for students to cope with different situations in life because of what the media models have shown, to a great extent with a mean of 3.77 and 3.69. They felt the sense of belonging to a great extent, whenever media suggests that every citizen participates in a national cause, as perceived by students and teachers, with a mean of 3.57 and 3.64. To a great extent, they were encouraged to share their things to others as they see and hear others share their things to the victims of calamities, with a mean of 3.72 and 3.68. To a great extent, it became easier for them to socialize wherever they go because of a common knowledge to talk about as provided by the media, with a mean of 3.79 and 3.83 .

\subsection{Significant Difference on the Perceptions of Students and Teachers on the Effect of Media Exposure to the Core Values of the Students}

Table5. Test of Significant Difference on the Perceptions of the Two Groups of Respondents as to the Effects of Media to the Institution's Core Values

\begin{tabular}{|l|l|c|c|c|}
\hline \multicolumn{1}{|c|}{ Groups } & Mean & t-value & P-value & Decision \\
\hline Students & 3.71 & 2.82 & 0.005 & Reject Ho \\
\hline Teachers & 3.57 & & & \\
\hline
\end{tabular}

With a probability value of 0.005 , which is lower than the 0.05 level of significance, the null hypothesis is rejected. Therefore, there is a significant difference between the perceptions of teachers and students as to the effects of media exposure to the students' core values. The mean perception of the students is 3.71, while the mean perception of the teachers is 3.57. Both values tell that media exposure affects the students' core values to a great extent. However, the mean perception of the students is greater than the mean perception of the teachers. This means that the effect of media exposure to the core values of students is perceived by the students to be greater than the perceived effect of the teachers. Specifically, they significantly differ along the core value of true Christian living. The students perceive that the effect of media exposure is to a great extent, while the teachers perceive it to a moderate extent. This implies that the students see the importance of their exposure to media in the development of their core value, more than the seen importance by the teachers.

\subsection{Correlation of the Effect of Media Exposure and the Profile of the Respondents vis-à-vis Louisian Core Values}

Table6. Test of Significant Relationship between the Effect of Media Exposure and the Profile of the Respondents vis-à-vis Core Values

\begin{tabular}{|c|c|c|c|c|c|c|c|c|c|}
\hline \multirow{3}{*}{\multicolumn{2}{|c|}{$\begin{array}{l}\text { Profile of the } \\
\text { Respondents }\end{array}$}} & \multicolumn{8}{|c|}{ Institutions' Core Values } \\
\hline & & \multicolumn{2}{|c|}{$\begin{array}{c}\text { True Christian } \\
\text { Living }\end{array}$} & \multicolumn{2}{|c|}{$\begin{array}{l}\text { Academic } \\
\text { Excellence }\end{array}$} & \multicolumn{2}{|c|}{$\begin{array}{c}\text { Professional } \\
\text { Responsibility }\end{array}$} & \multicolumn{2}{|c|}{$\begin{array}{l}\text { Social Awareness } \\
\text { and Involvement }\end{array}$} \\
\hline & & Value & decision & value & decision & value & decision & value & decision \\
\hline \multirow[t]{2}{*}{ Gender } & $\mathrm{r}$ & .01 & \multirow{2}{*}{$\begin{array}{l}\text { Accept } \\
\text { Ho }\end{array}$} & -.01 & \multirow{2}{*}{$\begin{array}{c}\text { Accept } \\
\text { Ho }\end{array}$} & .02 & \multirow{2}{*}{$\begin{array}{c}\text { Accept } \\
\text { Ho }\end{array}$} & .002 & \multirow{2}{*}{$\begin{array}{c}\text { Accept } \\
\text { Ho }\end{array}$} \\
\hline & $\mathrm{p}$ & .83 & & .89 & & .6 & & .97 & \\
\hline \multirow{2}{*}{$\begin{array}{l}\text { Educational } \\
\text { Level }\end{array}$} & $\mathrm{r}$ & -.17 & \multirow{2}{*}{$\begin{array}{c}\text { Reject } \\
\text { Ho }\end{array}$} & -.10 & \multirow{2}{*}{$\begin{array}{c}\text { Accept } \\
\text { Ho }\end{array}$} & -.13 & \multirow{2}{*}{$\begin{array}{c}\text { Reject } \\
\text { Ho }\end{array}$} & -.15 & \multirow{2}{*}{$\begin{array}{c}\text { Reject } \\
\text { Ho }\end{array}$} \\
\hline & $\mathrm{p}$ & .001 & & .06 & & .01 & & .004 & \\
\hline \multirow{2}{*}{$\begin{array}{l}\text { Family Monthly } \\
\text { Income }\end{array}$} & $\mathrm{r}$ & .014 & \multirow{2}{*}{$\begin{array}{l}\text { Accept } \\
\text { Ho }\end{array}$} & .09 & \multirow{2}{*}{$\begin{array}{c}\text { Accept } \\
\text { Ho }\end{array}$} & -.04 & \multirow{2}{*}{$\begin{array}{c}\text { Accept } \\
\text { Ho }\end{array}$} & -.01 & \multirow{2}{*}{$\begin{array}{c}\text { Accept } \\
\text { Ho }\end{array}$} \\
\hline & $\mathrm{p}$ & .79 & & .08 & & .47 & & .91 & \\
\hline
\end{tabular}




\begin{tabular}{|c|c|c|c|c|c|c|c|c|c|}
\hline \multirow[t]{2}{*}{ Religion } & $\mathrm{r}$ & -.09 & \multirow{2}{*}{$\begin{array}{c}\text { Accept } \\
\text { Ho }\end{array}$} & .03 & \multirow{2}{*}{$\begin{array}{c}\text { Accept } \\
\text { Ho }\end{array}$} & .03 & \multirow{2}{*}{$\begin{array}{c}\text { Accept } \\
\text { Ho }\end{array}$} & -.01 & \multirow{2}{*}{$\begin{array}{c}\text { Accept } \\
\text { Ho }\end{array}$} \\
\hline & $\mathrm{p}$ & .08 & & .50 & & .51 & & .86 & \\
\hline \multirow[t]{2}{*}{ Ethnicity } & $r$ & .06 & \multirow{2}{*}{$\begin{array}{c}\text { Accept } \\
\text { Ho }\end{array}$} & .01 & \multirow{2}{*}{$\begin{array}{c}\text { Accept } \\
\text { Ho }\end{array}$} & .05 & \multirow{2}{*}{$\begin{array}{c}\text { Accept } \\
\text { Ho }\end{array}$} & .05 & \multirow{2}{*}{$\begin{array}{c}\text { Accept } \\
\text { Ho }\end{array}$} \\
\hline & $\mathrm{p}$ & .25 & & .83 & & .35 & & .37 & \\
\hline \multirow{2}{*}{$\begin{array}{l}\text { Father's Educ- } \\
\text { ational Level }\end{array}$} & $\mathrm{r}$ & .03 & \multirow{2}{*}{$\begin{array}{c}\text { Accept } \\
\text { Ho }\end{array}$} & .04 & \multirow{2}{*}{$\begin{array}{c}\text { Accept } \\
\text { Ho }\end{array}$} & .06 & \multirow{2}{*}{$\begin{array}{c}\text { Accept } \\
\text { Ho }\end{array}$} & .05 & \multirow{2}{*}{$\begin{array}{c}\text { Accept } \\
\text { Ho }\end{array}$} \\
\hline & $\mathrm{p}$ & .59 & & .41 & & .22 & & .29 & \\
\hline \multirow{2}{*}{$\begin{array}{l}\text { Mother's Educ } \\
\text {-ational Level }\end{array}$} & $\mathrm{r}$ & .08 & \multirow{2}{*}{$\begin{array}{c}\text { Accept } \\
\text { Ho }\end{array}$} & .08 & \multirow{2}{*}{$\begin{array}{c}\text { Accept } \\
\text { Ho }\end{array}$} & .03 & \multirow{2}{*}{$\begin{array}{c}\text { Accept } \\
\text { Ho }\end{array}$} & .06 & \multirow{2}{*}{$\begin{array}{c}\text { Accept } \\
\text { Ho }\end{array}$} \\
\hline & $\mathrm{p}$ & .13 & & .14 & & .62 & & .25 & \\
\hline
\end{tabular}

$\mathrm{p}$ is significant @ 5\% level of significance

Table 6 presents the test of whether there is a significant relationship between the effect of media exposure and the profile of the respondents, on the four core values. At 0.05 level of significance, the $\mathrm{p}$ value under respondents' educational level profile is 0.001 for true Christian living, 0.01 for professional responsibility, and 0.004 for social awareness and involvement. Since the mentioned values are lower than the 0.05 , the null hypothesis is rejected. Therefore, there is a significant relationship between the effect of media exposure and the educational level of the respondents, along the core values of True Christian Living, Professional Responsibility, and Social Awareness and Involvement. This implies that educational level of students greatly influence the effects of media to the student core values. This is attributed to the fact that students as they grow older in the university, the higher the tendency that they embrace their core values and eventually have a higher tendency to manifest and apply it in their lives.

The $r$ values of $-0.17,-0.13,-0.15$ on the mentioned core values explain the indirect relationship between the effect of media exposure and the educational level of the respondents along the three core values. This means that, as educational level increases, the perceived effects of media exposure on the three core values decreases. This implies that, as the students become mature in terms of educational level, the effect of exposure to media to their three values becomes lesser.

Aside from the mentioned relationship, the table reveals that there is no significant relationship between the media exposure of the respondents and their profile vis-à-vis the core values. This means that the effects of media exposure to the core values are not affected by most of the profile of the respondents.

\section{CONCLuSion}

The study concludes that media exposure of college students greatly affects their manifestations of their school's core values which are true Christian Living, Academic excellence, professional responsibility, and social involvement and awareness. Further, significant difference exists on the assessment of teachers and students on the effects of media exposure to the core values of the students. And finally, the manifestations of the core values of the students with regard to their exposure to the different types of media are being affected by the educational level of students.

\section{RECOMMENDATIONS AND IMPLICATIONS FOR FURTHER RESEARCH}

Teachers of the students must be exposed also to the types of media to be made aware of the language of the students and to avoid the possible disturbing effects of generation gap.

Teachers should make use of media to strengthen the classroom discussions to help the students focus on types of media materials which are useful for them.

Parents and teachers should extend more adult guidance to younger audience of the media for the younger audiences are more vulnerable to the effects of media.

Acts of media role models should be purified in classroom discussion to help students become discriminate in their judgment about what is right and wrong.

A follow up study should be conducted on which form of media has the most important effect - print media, broadcast media, or electronic media - to find out what form of media should be utilized more by students as facilitated by classroom teachers.

A follow up study should also be conducted about the effect of media exposure to the cultural orientation of the students vis-à-vis their ethnic group to orient the students themselves about their cultural differences, which could also become an avenue for respect. 


\section{REFERENCES}

[1] Hope Cheong, Pauline. "Religion and social media: Got web?.” Media Development 58.1 (2011): 23.

[2] Kietzmann, Jan H., et al. "Social media? Get serious! Understanding the functional building blocks of social media." Business Horizons 54.3 (2011): 241-251.

[3] Lucas, Brian. "Social Communication Vatican II and the Australian Church." Australian e-Journal of Theology 19.2 (2012).

[4] Appiah, K. Anthony. "Liberal education: the United Sates example." (2003).

[5] Paine, Katie Delahaye. Measure what matters: Online tools for understanding customers, social media, engagement, and key relationships. John Wiley \& Sons, 2011.

[6] Ahmad, Ateeq. "Rising of social network websites in India overview." International Journal of Computer Science and Network Security 11.2 (2011): 155-158.

[7] Das, Biswajit, and Jyoti Shankar Sahoo. "Social networking site- A critical analysis of its impact on personal and social life." International Journal of Business and Social Science 2.14(2011).

[8] Tindowen, Darin Jan. "The catholicity of the University of Saint Louis." Asia-Pacific Journal of Multidisciplinary Research 3:5 (2015): 76-82.

[9] Coleman, Elizabeth Burns, and Kevin White, eds. Religious Tolerance, Education and the Curriculum. Springer Science and Buisness Media, 2011.

[10] Fessenden, Tracy."The nineteenth-century bible wars and the separation of church and state: Church History 74.4 (2005): 784-811.

[11] Kent Donlevy, J. "Catholic school administrators and the inclusion of non-Catholic students." Journal of Educational Administration 47.5 (2009): 586-608.

[12] Rainie, Lee, Aaron Smith, and Maeve Duggan. "Coming and going on Facebook." Pew Research Center's Internet and American Life Project (2013).

[13] Knight-McCord, Jasmine, et al. "What social media sites do college students use most?" Journal of Undergraduate Ethnic Minority Psychology 2(2016): 21.

[14] Ellison, Nicole B. "Social network sites: Definitions, history, and scholarship." Journal of ComputerMediated Communication.13.1 (2007): 210-230.

[15] Ezumah, Bellarmine A. “College students' use of social media: Site preferences, uses and gratifications theory revisited." International Journal of Business and Social Science 4.5 (2013).

[16] Ovadia, Steven. "ResearchGate and Academia.edu: Academic social networks." Behavioral \& Social Sciences Librarian 33.3 (2014): 165-169.

[17] White, Robert A. "The Media, Culture, and Religion Perspective: discovering a theory and methodology for studying media and religion." Communication Research Trends 26.1 (2007): 3-24.

[18] Mehmood, Saba, and Tarang Taswir. "The effects of social networking sites on the academic performance of students in college of applied sciences, Nizwa, Oman. International Journal of Arts and Commerce 2.1 (2013): 111-125.

[19] Boyd, D. M. and N.B.Elision."Timeline of the launch dates of many major Social Networking Sites." (2007).

[20] Coyle, Cheryl L., Heather Vaugn. "Social networking: Communication revolution or evolution?.” Bell Labs Technical Journal 13(2) (2008): 13-17.

[21] Rithika, M. and Sara Selvaraj.'Impact of social media on student's academic performance." International Journal of Logistics \& Supply Chain Management Perspectives 2.4 (2013): 636

[22] Kahne, Joseph, and Ellen Middaugh. "Digital media shapes youth participation in politics." Phi Delta Kappan 94.3 (2012): 52-56.

Citation: Mary Ann A. Balanza, Darin Jan C. Tindowen. "The Effects of Media Exposure to Students' Core Values" International Journal of Humanities Social Sciences and Education (IJHSSE), vol 6, no. 2, $2019, \mathrm{pp}$. 1-10. doi: http://dx.doi.org/10.20431/2349-0381.06020001.

Copyright: (C) 2019 Authors. This is an open-access article distributed under the terms of the Creative Commons Attribution License, which permits unrestricted use, distribution, and reproduction in any medium, provided the original author and source are credited. 